\title{
Viruses in the Pathogenesis of Allergy?
}

\author{
Maciej Kucharski* \\ Department of Food Safety and Veterinary Matters, Ministry of Agriculture and Rural Development, Poland
}

Submission: January 15, 2018; Published: March 07, 2018

"Corresponding author: Maciej Kucharski, Department of Food Safety and Veterinary Matters Ministry of Agriculture and Rural Development, Poland, Email: kucharz1980@interia.pl

\section{Abstract}

The paper describes the role of microorganisms in the course of atopic dermatitis. The study illustrates the influence of viral infections on the development of allergy in humans. The project describes a selection of viral infections that predispose to the development of allergic diseases.

Keywords: Viruses; Inflammation; Skin; Allergy

\section{Introduction}

The skin of each organism, apart from its protective functions and receiving senses actively participates in so-called immunity protection of the organism from being entered by different pathogens. The skin has its own SIS (Skin Immune System). It consists of Langerhans cells, dendritic cells, macrophages etc. On the surface of skin cells in healthy individuals, apart from the commensal flora, one can also find peptides that exhibit antibacterial activity. The peptides include defensins and cathelicidins which are synthetized by keratinocytes. In the course of atopic dermatitis the level of those proteins is considerably decreased. This, in turn, makes it easier for the pathogens to colonize the skin, which strengthens the inflammatory process.

Moreover, the disturbed process of apoptosis in immune cells, the fact that its proper functioning is impaired. All this makes the processes that are taking place in the skin more complicated [1,2].

It is known that during the course of allergic diseases such as atopic dermatitis, one can observe considerable colonization of the skin by the pathogens: Staphylococcus aureus. This pathogen during the pathogenesis of atopic dermatitis exhibits its activity through the cell wall for e.g. the teichoic acid and exotoxines. The teichoic acid, peptidoglycan, protein A may lead to the histamine release from the intracellular stores in basophils or in mast cells and, interestingly, influence the synthesis of immunoglobulins by suppressing IgA and IgG and increasing the level of IgE.

The enterotoxins that are produced by this pathogen have a similar effect to the allergens, entering into the deeper layers of the skin. Macrophages and Langerhans cells participate in this process. Enterotoxins exhibit a similar effect to the one of so-called superantigens. It leads to an increase in the synthesis of pro-inflammatory cytokines as well as to the activation of T lymphocytes.

What is more, the enzymes produced by Staphylococcus aureus (lipases, nucleases, haemolysins etc.) may lead to epidermis damage, which, makes it easier for the infection to be strengthened by other pathogens.

The second factor that participates in the sustaining of inflammatory process in the skin of individuals suffering from atopic dermatitis is the yeast called Malassezia sp. This pathogen is regarded as one of the allergens participating in the course of atopic dermatitis in humans as well as in animals. During the course of infection evoked by this microorganism, the Th2 response usually occurs. Th2 lymphocytes intensify the inflammatory process through the synthesis of cytokines that stimulate the production IgE. It applies to such cytokines as IL4, IL-5 etc. Malassezia sp., may also contribute to the activation of pathological inflammatory processes in the skin through the hydrolytic enzymes and lipases.

Yet yeast is Candida albicans. It lives for e.g. in the mucous membrane. Through the release of antigens, it stimulates an increase in the synthesis of cytokines including: IL-2 and interferon gamma increasing the inflammatory process in the skin. The allergens Candida sp. including: enolase, mannan and acid protease increase the inflammatory response dependent on $\operatorname{IgE}[3,4]$. One should also mention the two main species of house dust mites, whose allergens participate in the pathogenesis of atopy both in humans and in animals.

Those species are: Dermathophagoides pterynyssinus and Dermathophagoides farineae. Through the allergens Der $p 1$, Der $\mathrm{p} 2$, Der f 1, Der $\mathrm{f} 2$ they strengthen in inflammatory process in the skin of dogs suffering from atopic dermatitis. 
Itch "opens the gates" for other pathogens. It is one of the causes responsible for the hair loss in the places that are being scratched or the discoloration (licking). It is worth to give hypoallergenic food, protective medications etc. to the dogs that are predisposed to the development of atopic dermatitis, in advance [5].

What is the truth about the influence of viral infections on the course of allergy. Are those claims only hypotheses or facts? What is the connection between a viral infection and the development of atopic dermatitis?

It is a very interesting question from the epidemiological point of view in reference to different allergic diseases as well as well as from the perspective of the occurrence and the influence of infectious agents. Usually, in the pathogenesis of allergic diseases, apart from the microbiological component, environmental factors, individual factors, certain facts claiming that there is an influence of viral infections on the pathogenesis of those diseases are mentioned. This question is not unfounded since the disturbed apoptosis of the programmed cell death determined by physiology (for e.g. in cells that are infected by the EBV). Secondly, there is the influence of immunoglobins. Finally, there is also the viral latency that survived and the influence of the viral nucleic acid on the cell. One should also take into account the disruption of the cell homeostasis, its morphology. There is also the disrupted "barrier" that is composed of the infected skin cells in the respiratory tract etc.

It is known that viruses are built of nucleic acid (DNA or RNA) surrounded by a white shell known as capsid. The shape of viruses differs. It depends on the infectious characteristics of the virus itself as well on the factors connected with the individual that it infects.

Viral infection consists of the following five stages:

a. Attachment: The virus connects with the host cell using the receptors on its surface.

b. Entry: The nucleic acid enters the host cell.

c. Replication: Genetic material becomes replicated.

d. Maturation and Assembly : New virons are created in the host cell

e. Release: The host cell undergoes the process of lysis which releases the virons that are ready to infect other cells.

It was found that bacterial and viral infections are the cause that modulates the course of atopic dermatitis. The mast cells that are present on the skin surface - mastocytes, have a variety of different receptors on their surface including: Toll-like receptors TLR1, TLR2, TLR3 that recognize bacterial ligands and TLR8, TLR9 that recognize viral ligands.

By connecting the ligand with the receptor, the mast cell becomes activated. Degranulation takes place, inflammatory mediators are released, and the synthesis of eicosanoids, cytokines, chemokines etc. also takes place. Viruses, by infecting epithelial cells in the respiratory tract may disturb not only their morphology but also their internal homeostasis. It causes a break in the continuity of the epithelium in the vocal tract (the infection of cells by the rhinovirus where one can observe a loss of the ZO-1 protein from the synarthroses). It was also found that the rhinovirus may disturb the epithelial cells reconstruction. During a viral infection, epithelial cells synthetize and release cytokines and chemokines causing the influx of inflammatory cells to the focus of inflammation. Those cells are: neutrophils, eosinophils, NK cells, macrophages [6].

\section{The Epstein-Barr virus}

This virus is widespread around the world. It belongs to the Herpesvirideae family, the human is its natural host. Those individuals who become infected in the majority of cases are children. A person who becomes infected once, has the virus in his or her B lymphocytes. He or she has the DNA of the virus. The pathogen is responsible for causing the disease known as infectious mononucleosis etc. B lymphocytes and rarely $\mathrm{T}$ lymphocytes are the target cells (due to their long life).

Having been infected, the cells behave in two manners. The virus can either replicate quickly in the cell, virions are released and the cell dies or enters into the latent cycle, in the latent cycle the virus occurs in B lymphocytes. It undergoes the process of replication during the replication of the host cell. The virus is capable of blocking the apoptosis in the target cells [7].

Having been infected with the EBV, B lymphocytes synthetize IL-5. Cytokine is responsible for the eosinophils differentiation in bone marrow.. It activates mature eosinophils and extends the life of those cells in the tissues.

According to the Okudaira et al. hypothesis, in the course of allergy and atopy one can observe an increase in the IgE level that react with allergens and initiate inflammatory responses in tissues. The increased level of immnunoglobins may be caused by the fact of the increased synthesis of those immunologins by $B$ lymphocytes (immortalized by the Epstein-Barr virus).

The virus induces the synthesis of IL-2, IL-5 cytokines in B lymphocytes. The cytokines influence the development of the eosinophilic inflammation. This process takes place in the presence of IL-10. This cytokine is responsible for the expression of the bcl-2 protein (responsible for blocking apoptosis) in the cells of B lymphocytes that are infected with the EBV. On the other hand, the decrease of IL-12, INF -gamma by macrophages, suppresses the Th1 reaction and promotes the Th2 - which is dominant in allergic reactions [8]. It is surprising that in an allergic individual, an increase in the receptors for the rhinovirus or for the influenza virus on the respiratory tract epithelial cells [9]. When infected by HRSV, dendritic cells bind the IgE antigens through specific receptors. In the next stage, a signal towards the allergen-specific $\mathrm{T}$ lymphocytes present of the memory is produced - it means an increase in the expression of cytokines 
by Th2 lymphocytes and a development of allergic inflammation in the mucous membranes. However, those cytokines influence the transmission of the signal to the dendritic cell precursors in the bone marrow which, in turn, makes the new cells that are fully "equipped" to fight against the allergen arrive at the place of inflammation. Viruses have a tendency to infect Th2 (avoiding the attack of Th1 which enables them to disturb the proper functioning of the cell and remain "unnoticed" at the same time [10].

\section{Human respiratory syncytial virus (HRSV)}

In is a virus that has its viral envelope and a single RNA chain. Its target cells are the respiratory tract epithelial cells in humans. Having overcome the infection caused by this virus, the person is four times more likely to develop asthma. The cells infected by this virus have a decreased apoptosis process, disturbed antiviral response caused (amongst others) by the decreased synthesis of the interferon beta-1b. [11]. Those observations suggest that the recurring infections of cells by the virus, result in an increase in the synthesis of cytokines by Th2, and by an increase in the total IgE and MIP-1a levels (eosinophil protein).

\section{The influenza virus}

Doing research on mice, the mice infected with the influenza virus (at the moment when acute inflammation in the respiratory tract was diagnosed), the allergen of chicken egg albumin in spray was given to them. This, in turn, caused the occurrence of special IgE in the serum.

In a similar research, by Halt et al. on mice (they were infected with the influenza virus, the allergen of chicken egg albumin was given to them intraperitoneally) in the case of this model, special IgG were/was found as well as the decreased level of IgE. Certain tolerance to the chicken egg allergen was developed in that manner.

The information allows drawing the conclusion that the infection by the influenza virus does not lead to the development of tolerance to allergens but it fosters the development of allergic sensitization as well as the synthesis of IgE specific against the allergens.

The administration of the allergen of ovalbumin and infecting the cells by the influenza virus, resulted in an increase in the specific T lymphocytes, an increase in the IgE level as well as an increase in the Th2 response and the production of cytokines by Th2 lymphocytes. However, in the case when the infection with the influenza virus and the exposure to the chicken egg allergen (ovalbumin) were not simultaneous but separated in time with the period of 15-30 days, the $\mathrm{T}$ lymphocyte proliferation by ovalbumin was observed. The allergy was connected with a strong inflammatory response of the organism, IL-4, IL-5, IL13 synthesis and the level interferon gamma decreased. The Th1 lymphocytes were strongly suppressed. Moreover, it was possible to observe an increase in the synthesis of specific IgE as a result of the stimulation by the allergen (ovalbumin), an increase in the synthesis of IgG2a (OVA) occurred. The infection with the influenza virus prevents from the development of tolerance to the allergen and increases the synthesis of IgE, which strengthens the allergic inflammation, in the case when the infection by the virus follows the exposure to the allergen.

\section{Human respiratory syncytial virus}

When examining the influence of the infection with the virus on mice and the exposure to allergens (ovalbumin and ambrosia) during an acute infection, an increase in the level of $\operatorname{IgE}$ and $\operatorname{IgG}$ was observed. The inflammation of the respiratory tract caused by the virus also causes an increase in the permeability of mucous membrane for the allergens that are inhaled with the air. This, in turn, prevents from the development of tolerance to the allergen (which may be induced by the exposure to the allergen in the respiratory tract but only when it follows the infection with the influenza virus).

The influx of dendritic cells to the respiratory tract epithelium, resulting from an acute viral infection, may be one of the factors fostering the development of an allergic reaction for e.g. through the increased capture of the allergens and their presentation to the immune system cells [12].

Researching into Toll-like receptors, especially the TLR 3 and their influence either on the development or on the suppression of an allergic reaction. The stimulation by viral infection agents may contribute to making the course of the allergic inflammation more intense. It was found that (TLSP) lymphopoietin induces an allergic reaction that is dependent on Th2 lymphocytes affecting immature dendritic cells (an immature dendritic cell shows an increased CD134 expression and affecting immature $\mathrm{T}$ lymphocytes by driving their development towards TH2. In is known that those synthesize for example. IL-4 affecting the synthesis of IgE and strengthening the allergic reaction), by stimulating them so synthetize for e.g. IL-8, eotaxins or a variety of chemokines. It is the mediators of inflammation that intensify the influx of cells - neutrophiles, eozynophiles, and Th2 limphocytes to the place of inflammation. This results in the development of the focus of inflammation in the future.

\section{Respiratory infections in dogs.}

A variety of different viruses and bacteria can be found in dogs within the course of the respiratory tract inflammation. One should mention such pathogens as: Bordetella bronchiseptica, parainfluenza virus (CPiV), adenovirus type 2 (CAV), canine distemper virus (CDV), influenza virus (CIV), respiratory coronavirus (CRCoV) and others.

Pappies are more prone to become infected with those viruses since on the one hand, there is the insufficient level of maternal antibodies protecting them from the infection and on the other hand, there is the problem of ineffective vaccination or of disturbed functioning of the immune system. However, it 
may be also caused by the fact that some owners of dog breeding sites are motivated only by their profit and the dog's health is of secondary meaning to them.

Moreover, there are the characteristics of pathogens themselves including their virulence, short or long incubation period, resilience to the conditions of the external environment. The pathogens causing infections of the respiratory tract are excreted from the organism by droplets. This in turn, makes it easy for them spread in the surrounding environment.

The usage of vaccinations that are used to prevent from the respiratory tract infections does not protect the dog completely but gives it only partial immunity against the pathogens. It is often found in dogs that the occurrence of clinical symptoms follows the excretion of the viruses. It poses a significant problem both when it comes to the prevention and to the treatment of dogs.

But what may be the connection between the influence of pathogens attacking the dog and the development of allergy either instantly or within the course of dog's further life? It is a complex question and it is difficult to give a clear answer to it. On the other hand, there is the evidence for the participation of viruses in the pathogenesis of allergic diseases in humans; on the other hand, the results of different studies are sometimes contradictory. It is possible that the time of being exposed to the infection plays a crucial role here [13-15].

Through the mechanism of the infections of the respiratory tract cells by the viruses, their immortalization and the disturbance of their internal homeostasis, the viruses influence the development of allergy in sensitive individuals in an unknown manner.

Apart from the infective agents, one should also take into account the genetic, environmental and individual factors. A dog living in either the same or similar environmental conditions as a human, at the same period of its life is exposed to numerous factors which result in the occurrence of the symptoms of atopy in one individual, leaving other individual healthy. When browsing through the internet, one can come to the conclusion that there is either no or little information on the discussed subject in dogs. There are reports informing about the infection of the English Whippet by the influenza virus as well as about the occurrence of similar symptoms in dogs and in humans [15-20].

Certain breeds of dogs are predisposed to the improper functioning of the immune system. Therefore, administering either weakened or killed viruses to them should be monitored later.

Is there such an influence of the viruses on the development of allergic inflammation? It seems that much has yet to be discovered in the question of why a given dog suffers from atopic dermatitis with all its symptoms whereas the other does not [2124].

\section{References}

1. Kyra VW, (2008) Expression of endogenous antimicrobial peptides in normal canine skin. Journal of Veterinary Dermatology 20(1): 19-26.

2. Rutkowska J (2007) Zjawisko apoptozy w chorobach alergicznych. Nowiny Lekarskie 76(1): 48-54.

3. Nowicki R (2005) Rola infekcji w zespole atopowego zapalenia skóry (wyprysku atopowym). Przegląd Alergologiczny.

4. Kasperska ZA, Edmund R (2002) Candida albicans-czynnik przyczynowy chorób alergicznych. Alergia Astma Immunologia 7(4):170-173.

5. DeBoer DJ, Marsella R (2001) The ACDV task force on canine atopic dermatitis (XII): the relationship of cutaneuos infection to the pathogenesis and clinical course of canine atopic dermatitis.Veterinary Immunology and Immunopathology 81(3-4): 239-249.

6. Sylwia M, Marek LK (2012) Odpowiedź przeciwwirusowa w nabłonkach dróg oddechowych: rola w patogenezie zaostrzeń astmy oskrzelowej.Alergia Astma Immunologia 17(3): 127-135.

7. Joanna B, Danuta JL (2011) Zakażenia EBV -cykl życiowy, metody diagnostyki, chorobotwórczość. Postepy Hig Med Dosw (online) 65: 286-298.

8. Anna S, Anna SP (2005) Rola wirusa EBV w patogenezie chorób alergicznych. Alergia Astma immunologia 10(4): 169-174.

9. Tantilipikorn P, Auewarakul P (2011) Airway allergy and viral infection. Asian Pac J Allergy Immunol 29(2): 113-119.

10. Holt PG (2011) Infection and the development of allergic disease. Allergy 66 (Supl. 95): 13-15.

11. Sylwia Moskwa, Marek L. Kowalskio Dpowiedź przeciwwirusowa w nabłonkach dróg oddechowych - rola w patogenezie zaostrzeń astmy oskrzelowej.

12. Schwarze J, Gelfand EW (2002) Respiratory viral infections as promoters of allergic sensitization and asthma in animal models. Eur Respir J 19(2): 341-349.

13. Zemann B, Schwaerzler C, Griot WM, Nefzger M, Mayer P et al. (2003) Oral administration of specific antigens to allergy-prone infant dogs induces IL-10 and TGF- expression and prevents allergy in adult life. J Allergy Clin Immunol 111(5): 1069-1075.

14. Anna KL (2006) Early life cytokines, viral infections and IgE-mediated allergic disease. Department of Immunology, Stockholm University, Sweden.

15. Buonavoglia C, Martella V (2007) Canine respiratory viruses. Vet Res 38(2): 355-373 355.

16. Adamek GT, Tomaz G, Grazyna CM, Julyuz P (2001) Znaczenie obniżonej odporności na infekcje w patogenezie atopowego zapalenia skóry: rola Staphylococcus aureus.Alergia Astma Immunologia 6(4): 169-179.

17. Elzbieta R, Tomasz J, Anna Macura, Jacek Bieleck (2013) Charakterystyka Grzybów z Rodzaju Malassezia sp. II Aspekty Kliniczne. Post Mikrobiol 52(3): 307-314

18. Kyoung JY, Vickie LC, Kent JS, Karen MH, Bruce HJ (2005) Influenza Virus Infection in Racing GreyHounds. Emerging Infectious Diseases $11(12)$.

19. Kucharski Maciej Alergeny pokarmowe. Weterynaria w Praktyce Kwiecień 4/2011, Kucharski Maciej Wybrane cytokiny w atopowym zapaleniu skóry u psów.Weterynaria w Praktyce, Marzec 3/2011.

20. Kucharski Maciej Pchła kocia i alergiczne pchle zapalenie skóry. Weterynaria w Praktyce Styczeń- Luty 1-2/2011. 
21. Kucharski Maciej Zakażenie Staphylococcus sp. jako powikłanie atopowego zapalenia skóry u psów.Magazyn Weterynaryjny vol 20. nr 164. 01' 2011.

22. Kucharski Maciej Alergeny grzybów w atopowym zapaleniu skóry u psów.Weterynaria w Praktyce, Październik 10/2010.
23. Kucharski Maciej,Wybrane mechanizmy komórkowe w atopowy zapaleniu skóry u psów.

1. Weterynaria, nr. 1-2, $2015 \mathrm{r}$.

24. Kucharski Maciej,Genetyczne podłoże atopowego zapalenia skóry u psów. Weterynaria, nr. 3, 2015r.

\begin{tabular}{l} 
Your next submission with Juniper Publishers \\
will reach you the below assets \\
- Quality Editorial service \\
- Swift Peer Review \\
- Reprints availability \\
- E-prints Service \\
- Manuscript Podcast for convenient understanding \\
- Global attainment for your research \\
- Manuscript accessibility in different formats \\
( Pdf, E-pub, Full Text, Audio) \\
- Unceasing customer service \\
Track the below URL for one-step submission \\
https://juniperpublishers.com/online-submission.php \\
\hline
\end{tabular}

